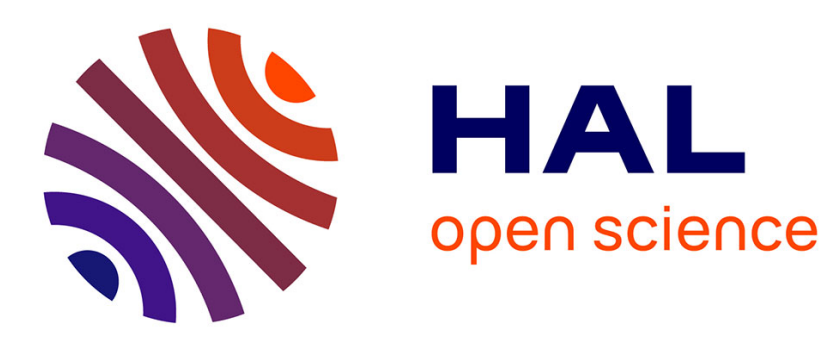

\title{
Synthesis and characterization of fluorinated copolyetherimides with -CH2-C6F13 side chains based on the ULTEM structure
}

Meriyam Kaba, Ricardo Escarcena Romero, Azzouz Essamri, André Mas

\section{To cite this version:}

Meriyam Kaba, Ricardo Escarcena Romero, Azzouz Essamri, André Mas. Synthesis and characterization of fluorinated copolyetherimides with -CH2-C6F13 side chains based on the ULTEM structure. Journal of Fluorine Chemistry, 2005, 126 (11-12), pp.1476-1486. 10.1016/j.jfluchem.2005.07.014 . hal-00382963

\section{HAL Id: hal-00382963 https://hal.science/hal-00382963}

Submitted on 11 May 2009

HAL is a multi-disciplinary open access archive for the deposit and dissemination of scientific research documents, whether they are published or not. The documents may come from teaching and research institutions in France or abroad, or from public or private research centers.
L'archive ouverte pluridisciplinaire $\mathbf{H A L}$, est destinée au dépôt et à la diffusion de documents scientifiques de niveau recherche, publiés ou non, émanant des établissements d'enseignement et de recherche français ou étrangers, des laboratoires publics ou privés. 
Synthesis and characterization of fluorinated copolyetherimides with $-\mathrm{CH}_{2}-\mathrm{C}_{6} \mathrm{~F}_{13}$ side chains based on the ULTEM ${ }^{\mathrm{TM}}$ structure

Meriyam Kaba ${ }^{\mathrm{a}, \mathrm{b}}$, Ricardo Escarcena Romero ${ }^{\mathrm{a}}$, Azzouz Essamri ${ }^{\text {, }}$, André Mas ${ }^{\mathrm{a}}$

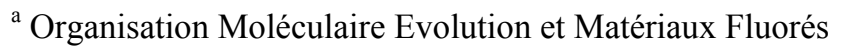

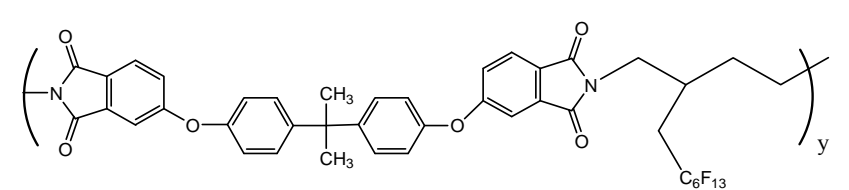
UMR 5073 CNRS, Université Montpellier II,

Place Eugène Bataillon, 34095 Montpellier Cedex 5, France

${ }^{\mathrm{b}}$ Faculté des Sciences, Laboratoire de Génie des Procédés, Université Ibn Tofail, BP 133 Kénitra, Morocco

The hydrophobicity and the thermal properties of soft non-porous films are studied. 


\title{
Synthesis and characterization of fluorinated copolyetherimides with $-\mathrm{CH}_{2}-\mathrm{C}_{6} \mathbf{F}_{13}$ side chains based on the ULTEM ${ }^{\mathrm{TM}}$ structure
}

\author{
Meriyam Kaba ${ }^{\mathrm{a}, \mathrm{b}}$, Ricardo Escarcena Romero ${ }^{\mathrm{a}}$, Azzouz Essamri ${ }^{\mathrm{b}}$, André Mas ${ }^{\mathrm{a}^{*}}$ \\ a Organisation Moléculaire Evolution et Matériaux Fluorés, UMR 5073 CNRS, Université \\ Montpellier II, Place Eugène Bataillon, 34095 Montpellier Cedex 5, France \\ ${ }^{\mathrm{b}}$ Faculté des Sciences, Laboratoire de Génie des Procédés, Université Ibn Tofail, BP 133 \\ Kénitra, Morocco
}

\begin{abstract}
Step polymerization of Bisphenol-A diphthalic anhydride (BAPA) with various mixtures from m-phenylene diamine (m-PDA) and 2-(perfluorohexylmethyl)butan-1,4-diamine (TFD) led to hydrophobic copolyetherimides bearing $\mathrm{R}_{\mathrm{F}}=-\mathrm{CH}_{2}-\mathrm{C}_{6} \mathrm{~F}_{13}$ side chains that were characterized by NMR, elementary analysis, DSC, TGA and surface energy analysis. By increasing the TFD unit $\%$, the glass transition temperature $\left(\mathrm{T}_{\mathrm{g}}\right)$ decreases according to the Fox equation from $217{ }^{\circ} \mathrm{C}$ (m-PDA $100 \%$ and TFD $0 \%$ like in $\left.\mathrm{ULTEM}^{\mathrm{TM}} 1000\right)$ to $113{ }^{\circ} \mathrm{C}$ (m-PDA $0 \%$ and TFD $100 \%$ ). Similarly the surface energy $\left(\gamma_{\mathrm{s}}\right)$ decreases from $45.3 \mathrm{~mJ} \mathrm{~m}^{-2}$ to $27.4 \mathrm{~mJ} \mathrm{~m}^{-2}$. The thermal decomposition temperature ( $\mathrm{T}_{\mathrm{d}}$ for $5 \%$ weight loss under argon) is slightly affected by introducing TFD units compared with Td for ULTEM ${ }^{\mathrm{TM}}$ and it is close to $400{ }^{\circ} \mathrm{C}$. The best compromise between thermal stability, hydrophobic and organophilic properties as well as the ability to form a soft non-porous film by the cast-evaporating method led us to select the copolyetherimide with m-PDA $25 \%$ and TFD 75\% for which $\mathrm{T}_{\mathrm{g}}=121^{\circ} \mathrm{C}, \mathrm{T}_{\mathrm{d}}=400$ ${ }^{\circ} \mathrm{C}$ and $\gamma_{\mathrm{s}}=30.8 \mathrm{~mJ} \mathrm{~m}^{-2}$.
\end{abstract}

Keywords : Fluorinated polyetherimide; Hydrophobic non-porous films; Cast membrane

\footnotetext{
* Corresponding author

E-mail address: mas@univ-montp2.fr (A. Mas).
} 


\section{Introduction}

The thermal stability, hydrolytic resistance and solubility in organic solvents of aromatic polyetherimides can be enhanced by fluorinated groups judiciously fixed on the appropriate sites of the polymer backbone. Resins from fluorinated polyetherimides showing such structural properties combined with more specific properties have very important applications in microelectronics [1] and composite materials.

The fluorinated groups are usually introduced into the macromolecular chain via a fluorinated dianhydride monomer or/and a fluorinated diamine monomer in the case of the most common step-polymerization [2,3]. For example the fluorinated polyetherimide prepared from 2,2bis(3,4-dicarboxyphenyl)hexafluoropropane dianhydride (6FDA) and 2,2'-bis[4-(4aminophenoxy)diphenyl] hexafluoropropane (BDAF) exhibites a glass transition temperature ( $\mathrm{T}_{\mathrm{g}}$ ) of $270{ }^{\circ} \mathrm{C}$, a long-term thermo-oxidative stability and a reduced water absorption relative to non-fluorinated samples [4]. In spite of the flexibility brought from the ether linkage in the macromolecular chain, some fluorinated polyetherimides have a structural rigidity that leads to a delicate processability and a great fragility of the final materials. This special feature imposes a limitation on the use of these polymers for some applications, notably for the spincoating technique and the deposition of a thin-protective layer or a specific-property layer. By introducing in the chain aliphatic carbon segments associated with the ether linkage, of course the softness of the final material increases but a negative effect is the decrease of $T_{g}$ that leads to a possible reduction in thermal stability. To optimize the properties of the polymer, the flexibility of the chain must be improved without a strong decrease of $\mathrm{T}_{\mathrm{g}}$.

Among all applications for which polyimides are good-candidate materials, a very high thermal stability as well as a high $\mathrm{T}_{\mathrm{g}}$ are not required for applications such as membrane separation techniques particularly to elaborate non-porous membranes. In this field the fluorinated copolyetherimides are being more and more used. These materials are the subject of a major development because of its interesting hydrophobic and organophilic properties. They are particularly used for the separation of organic-organic liquid mixtures and for the extraction of volatile organic compounds (VOC) from water by the pervaporation process $[5,6]$. Nevertheless the flexibility of the chains is a necessary condition to swell the membrane and to possibly obtain good transfert properties. For that, new polymers and modified polymers obtained by crosslinking, grafting or blending are required in order to prepare easy processing materials, soft non-porous membranes as well as coatings. After modification of 
the polymer structure, of course the hydrophobic character and the hydrolytic stability of the fluorinated polyetherimides are to be maintained.

The well-known polyetherimide ULTEM $^{\mathrm{TM}} 1000$ (manufactured and marketed by General Electric Plastic) obtained by step-polymerization of bisphenol-A diphthalic anhydride (BAPA) and m-phenylenediamine (m-PDA), is widely used in microelectronics and in membrane field for gas separation [7] and, more recently but to a lesser extent, for pervaporation [8]. Surprisingly ULTEM $^{\mathrm{TM}} 1000$ was the subject of few works in order to synthesize new ULTEM structure-based copolyetherimides and related non-porous membranes. The main experiments were about the increase of hydrophilicity by chemical surface functionalization as well as plasma treatment [9]. The increase of hydrophobicity was also studied for example by blending ULTEM $^{\mathrm{TM}} 1000$ with oligomeric fluoropolymers synthesized by polyurethane chemistry and tailored with fluorinated end groups [10].

The purpose of the present study is to prepare and characterize fluorinated copolyetherimides based on the ULTEM ${ }^{\mathrm{TM}}$ structure where m-PDA is gradually replaced by an aliphatic diamine bearing the long perfluorinated side chain $\mathrm{R}_{\mathrm{F}}=-\mathrm{CH}_{2}-\mathrm{C}_{6} \mathrm{~F}_{13}$. The effects of the composition of the copolymer on the hydrophobicity and the thermal properties are analyzed. A rough estimation of the softness of cast films is also made. We selected the copolymer showing the best combination between all these properties to elaborate non-porous membranes.

Shortly these materials will be tested as pervaporation membranes. By varying the number of the hydrophobic side chains in the copolymer, the physical properties of the membranes as well as its accessible volume to the permeated molecules, could be partly controlled. By this way, the flux and the selectivity of the VOC through the membrane, particularly the traces of chlorinated solvents from water, could be studied and related to the structure of the macromolecular chain.

\section{Results and discussion}

\subsection{Synthesis and structural characterization of the fluorinated polyetherimides}

It is well known that the long perfluoroalkyl chains $\mathrm{R}_{\mathrm{F}}$ bring a strong contribution to the hydrophobicity, particularly by the terminal trifluoromethyl group. Only a few fluorinated aliphatic diamines with such side chains are available and can be used as starting monomers for the synthesis of polyimides. In previous articles we reported the synthesis of 
2,3-bis(2,2,3,3,4,4,5,5,5-nonafluoropentyl)butan-1,4-diamine and 2-(2,2,3,3,4,4,5,5,6,6,7,7,7tridecafluoroheptyl)butan-1,4-diamine respectively called NFD and TFD.

The NFD diamine led to polyetherimide bearing two side chains $-\mathrm{CH}_{2} \mathrm{C}_{4} \mathrm{~F}_{9}$ [11] per monomer unit whereas the TFD diamine [12] that is the subject of this article, led to polyetherimide bearing one side chain $-\mathrm{CH}_{2} \mathrm{C}_{6} \mathrm{~F}_{13}$ per monomer unit. The scheme of the synthesis of fluorinated copolyetherimides by the step reaction of BAPA with various mixtures of m-PDA and TFD is shown in Fig.1.

The selected molar fractions of TFD in the mixture of diamine were $0,0.10,0.18,0.25,0.50$, $0.75,0.90$ and 1 . The polymer obtained from TFD/m-PDA in the ratio $0 / 1$ was called UPEI, it shows the same structure as ULTEM ${ }^{\mathrm{TM}} 1000$ developed by General Electric Plastics. It is used as a reference structure for doing a best comparison between non-fluorinated and fluorinated polyetherimides. So, all the materials have been prepared in our laboratory. The polymer obtained from TFD/m-PDA in the ratio $1 / 0$ and the copolyetherimides obtained from the various mixtures were called FPEI and coFPEI respectively. All compositions from 0.10 to 0.90 led to the formation of copolymers that were characterized.

This article reports the structural results (NMR, DSC, GTA, elementary analysis) concerning the following molar fractions $0,0.25,0.50,0.75$ and 1 for that the same equipment was used and similar analysis were performed. All the values in the composition range are given for the wettability, the surface energy and the resistance-test of the films.

The ${ }^{1} \mathrm{H}$ NMR spectra of some samples reproduced in Fig.2 show that the molar fraction of fluorinated units (y in Tab.1) can be easily determined by the ratio of the intensity of both signals of methylene $-\mathrm{CH}_{2}-\mathrm{N}(\mathrm{CO})_{2}$ and methyle $-\mathrm{CH}_{3}$ groups, respectively $\mathrm{I}_{\mathrm{CH} 2-\mathrm{N}(\mathrm{CO}) 2}$ and I $\mathrm{CH} 3$ (equation 1).

$$
\mathrm{y}=1 / 4 \mathrm{I}_{\mathrm{CH} 2-\mathrm{N}(\mathrm{CO}) 2} / 1 / 6 \mathrm{I}_{\mathrm{CH} 3}
$$

By this method we obtained approximate values of the contents in the copolymers, nevertheless the y value deduced is consistent with the initial composition of the m-PDA and TFD monomer mixtures for long reaction time. The similar composition of monomers mixtures and related copolymers suggests that the full amount of diamine was incorporated in the macromolecular chain in spite of the likely difference in reactivity between m-PDA and 
TFD. Indeed the high yield, close to $96 \%$, obtained for the solid polyetherimide, confirmed the almost complete incorporation of dianhydride and both diamines in the copolymer, nevertheless the molecular weights (Tab.1) seem to show that TFD is not as reactive as mPDA under these experimental conditions. The weight fraction of fluorinated units ( $\mathrm{w}$ in Tab.1) then the fluorine weight percentage (Fluorine wt \%) were deduced from y considering the molecular weight of the non-fluorinated $\left(\mathrm{M}_{\mathrm{m}-\mathrm{PDA}}\right.$ with $\left.\mathrm{C}_{37} \mathrm{H}_{24} \mathrm{O}_{6} \mathrm{~N}_{2}=592\right)$ and fluorinated $\left(\mathrm{M}_{\text {TFD }}\right.$ with $\left.\mathrm{C}_{42} \mathrm{H}_{29} \mathrm{~F}_{13} \mathrm{O}_{6} \mathrm{~N}_{2}=904\right)$ units.

The following equations ( 2 and 3 ) were used:

$$
\begin{gathered}
\mathrm{w}=\mathrm{M}_{\mathrm{TFD}} \mathrm{y} / \mathrm{M}_{\mathrm{TFD}} \mathrm{y}+\mathrm{M}_{\mathrm{m}-\mathrm{PDA}}(1-\mathrm{y}) \\
\mathrm{F} \%=100(19 \times 13) \mathrm{y} / \mathrm{M}_{\mathrm{TFD}} \mathrm{y}+\mathrm{M}_{\mathrm{m}-\mathrm{PDA}}(1-\mathrm{y})
\end{gathered}
$$

The comparison of the Fluorine wt \% resulting from NMR by this way and from elementary analysis (Tab. $1^{\mathrm{c}}$ and $1^{\mathrm{d}}$ respectively) show slightly lower values for elementary analysis determination. The difference in values between the two techniques can be generally explained by an incomplete combustion of the fluorined samples during the analysis that leads to a lower Fluorine \% estimation.

The ${ }^{19} \mathrm{~F}$ NMR spectrum of coFPEI 75/25 (Fig.3) showed the characteristic peaks of the $\mathrm{R}_{\mathrm{F}}$ chain at $\delta(\mathrm{ppm})-81.0\left(\mathrm{CF}_{3}\right),-112.9,-121.9,-123.0,-123.7,-126.4\left(5 \mathrm{CF}_{2}\right)$ that were very close for coPEI and FPEI.

\subsection{Influence of the fluorinated unit content on the thermal properties of the polyetherimides}

$\mathrm{T}_{\mathrm{g}}$ decreases from UPEI to FPEI depending on the increase of the molar fraction of the fluorinated units (Tab.1). The easier mobility of the polymer chain at low temperature is attributable to the aliphatic segments - $\left(\mathrm{CH}_{2}\right)_{4}$ - of TFD units incorporated in the main chain as well as to the bulky $-\mathrm{CH}_{2}-\mathrm{C}_{6} \mathrm{~F}_{13}$ side chains. The gradual effect of the TFD weight fraction on the $T_{g}$ value is shown in Fig.4. Experimental $T_{g}$ have a good correlation with the predicted $T_{g}$ 
according to the Fox and Couchman methods $[13,14]$. Based on the average values of the depicted straight lines, a fall of $1{ }^{\circ} \mathrm{C}$ for $\mathrm{T}_{\mathrm{g}}$ is approximately due to a supplementary incorporation of 0.01 TFD unit weight fraction in the copolymer.

In Tab.2 and Fig.5a, are reported the thermogravimetric characteristics and TG curves of polyetherimides obtained under argon. As shown, the fluorinated polyetherimides start decomposing at a lower temperature than UPEI $\left(\mathrm{T}_{\mathrm{d}} 5 \%=400{ }^{\circ} \mathrm{C}\right.$ and $500{ }^{\circ} \mathrm{C}$ respectively) (Fig.5a). In fact for this comparison, the temperature corresponding to a 5\% weight loss was considered $\left(\mathrm{T}_{\mathrm{d}} 5 \%\right)$. It is significant that $\mathrm{T}_{\mathrm{d}} 5 \%$ increases with the fluorine weight $\%\left(\mathrm{~T}_{\mathrm{d}} 5 \%=\right.$ $460{ }^{\circ} \mathrm{C}$ for $\mathrm{FPEI}$ ). The maximum rate of decomposition of UPEI for the $\mathrm{T}_{\max }$ temperature is followed by a less marked decomposition step; similar behaviour is not so obvious for coFPEI for which only one decomposition step clearly appears (DTG not shown). For FPEI, the DTG curve shows the maximum rate of decomposition at $\mathrm{T}_{\max }=508{ }^{\circ} \mathrm{C}$ and a weak shoulder at 440 ${ }^{\circ} \mathrm{C}$. At $800{ }^{\circ} \mathrm{C}$ a charred residue was left in the $13-48 \mathrm{w} \%$ range for all polymers. The $13 \%$ residue was left by FPEI.

In Fig.5b, TG curves were obtained under air. These results are different when they are compared to the results under argon atmosphere. A slight decrease of $T_{d} 5 \%$ and $T_{\max }$ was noticed as well as two decomposition steps for all polyetherimides. Moreover no residue was left at $750{ }^{\circ} \mathrm{C}$, this is due to a more complete and quick combustion of the polymers in air. Under argon and air, the weight loss at $200-300{ }^{\circ} \mathrm{C}$ range is related to the elimination of traces of the NMP solvent anyway present in the polymers in spite of the fact that the samples were carefully dried. The strong interactions between the polymer and the solvent impose to reach a higher temperature than the boiling point of the solvent $\left(\mathrm{T}_{\mathrm{eb}} \mathrm{NMP}=202{ }^{\circ} \mathrm{C}\right)$ to entirely burn it away. For coFPEI, more particularly for coFPEI 25/75 (curves b in Fig.5), the weight loss close to $6 \%$ at $200{ }^{\circ} \mathrm{C}$ can be partly attributed to the decomposition of NMP solvent as well as to the decomposition of unreacted starting molecules possibly present in this analyzed sample. We cannot exclude the possibility that a complete imidization of the amic-acid intermediate in these conditions is achieved.

The combination of mass spectrometry with thermogravimetric analysis (MS-TGA) allowed more information to be obtained about the gas compounds produced during the temperature upward run. The MS-TGA coupling technique was performed for the analysis of the degradative process under argon. Only the higher mass loss for UPEI and FPEI were analyzed. 
As indicated above two decomposition steps were identified for UPEI under argon at $\mathrm{T}_{\max 1}=$ $533{ }^{\circ} \mathrm{C}$ and $\mathrm{T}_{\max 2}=585{ }^{\circ} \mathrm{C}$ with the maximum decomposition rates of $7 \% / \mathrm{min}$ and $1.8 \% /$ min respectively.

The evolution profiles of the main emited gas from UPEI at $533{ }^{\circ} \mathrm{C}$ under argon (Fig. $6 \mathrm{a}_{1}$ ) show the extraction of phenol and benzonitrile that present a similar fragmentation and the most intense peaks following : $\mathrm{m} / \mathrm{z}=94,66,65,63,51,50$. The presence of $\mathrm{CO}_{2}$ and $\mathrm{CO}$ $(\mathrm{m} / \mathrm{z}=44,28) ; \mathrm{CH}_{4}(\mathrm{~m} / \mathrm{z}=16,15,14)$ and $\mathrm{H}_{2} \mathrm{O}(\mathrm{m} / \mathrm{z}=18,17)$ was also detected. $\mathrm{CO}_{2}+\mathrm{CO}$ were attributed to a degradation involving an initial hydrolysis of the imid group in first step due to traces of absorbed water. An intermediate amic-acid structure could be also formed besides the non-hydrolyzed imid ring that breaks with heat in subsequent step [15]. The amicacid structure uncompletely imidized at the end of the polymerization could also participate to the formation of water. It was shown that the simultaneous cleavage of ether linkage and isopropylydene group led to the formation of water, also available for catalyzing the hydrolysis of the imid group [16]. The initial hydrolysis led to the appearance of $\mathrm{CO}+\mathrm{CO}_{2}$ at a temperature less high than the temperature of all products from pyrolysis at about $400{ }^{\circ} \mathrm{C}$ (Fig. $\left.6 \mathrm{a}_{3}, \mathrm{a}_{5}\right)$. Phenol $(\mathrm{m} / \mathrm{z}=94,66)$ and benzene $(\mathrm{m} / \mathrm{z}=78,77,52,51,50)$ begin to appear at about $460{ }^{\circ} \mathrm{C}$ ( Fig. $6 \mathrm{a}_{4}$ ) and reach the maximum amount at about $580{ }^{\circ} \mathrm{C}$ indicating that these pyrolysis products were formed in second step [16]. After decarboxylation the intermediate amic-acid structure could be done imino forms leading to nitrile group by dehydratation [15].

Two decomposition steps were also identified for FPEI under argon at $\mathrm{T}_{\max 1}=440{ }^{\circ} \mathrm{C}$ (weak shoulder) and $\mathrm{T}_{\max 2}=508{ }^{\circ} \mathrm{C}$ with the maximum decomposition rates of $3 \% / \mathrm{min}$ and 13.2 $\%$ / min respectively. At $508^{\circ} \mathrm{C}$ a comparison with UPEI leads to a similar assignments of the main peaks related to the formation of phenol and benzonitrile ( $\mathrm{m} / \mathrm{z}=94$ (weak), 66, 65, 51), $\mathrm{CO}_{2}+\mathrm{CO}(\mathrm{m} / \mathrm{z}=44,28)$, methane $(\mathrm{m} / \mathrm{z}=16,15,14,13)$ then $\mathrm{H}_{2} \mathrm{O}(\mathrm{m} / \mathrm{z}=18)\left(\right.$ Fig.7 $\left.\mathrm{b}_{1}\right)$. Fig. $7 b_{2}$ clearly shows the appearance of $\mathrm{CO}_{2}$. New peaks seems to be attributable to the aliphatic chain of the backbone structure consequently assigned to the fragments $\mathrm{CH}_{2} \mathrm{NH}_{2}$ $(\mathrm{m} / \mathrm{z}=30), \mathrm{C}_{2} \mathrm{H}_{5}(\mathrm{~m} / \mathrm{z}=29,28,27,26)\left(\right.$ Fig. $\left.7 \mathrm{~b}_{3}\right)$ as well as to the perfluorinated side chain cleavage characterized by the typical fragments following: $\mathrm{CF}_{3}(\mathrm{~m} / \mathrm{z}=69)\left(\right.$ Fig. $\left.7 \mathrm{~b}_{4}\right)$ and $\mathrm{CF}$ $(\mathrm{m} / \mathrm{z}=31)\left(\right.$ Fig. $\left.7 \mathrm{~b}_{3}\right)$. This behaviour can be supported by a similar interpretation as UPEI by considering the existence of amic-acid and imino structures.

The scheme of a possible mechanism of the thermal degradation of FPEI is summarized in Fig.8. 
2.3. Influence of the fluorinated unit content on the wettability and surface energy of the polyetherimides

The difference in contact angles and surface energy values [17] for ULTEM ${ }^{\mathrm{TM}}$ and UPEI films (Tab.3) are certainly due to different surface states arising from their respective preparation methods, that is to say extrusion for ULTEM ${ }^{\mathrm{TM}}$ film and cast-evaporating for UPEI film. The wettability measurements are particularly sensitive to the rugosity and surface density of the fil; it is important to compare the surface properties of coFPEI and FPEI samples with those of UPEI obtained by the same way.

As the TFD monomer units increase in the polymer, $\theta_{\mathrm{H} 2 \mathrm{O}}$ increases from $88^{\circ}$ to $92^{\circ}$ showing a minimal value for coFPEI $25 / 75$ and 50/50 whereas $\theta_{\mathrm{I} 2 \mathrm{CH} 2}$ increases regularly. Such evolution of contact angles with the copolymer composition could be related with the possible reorientation of polar groups at the top surface. Further investigations are necessary to study in-depth and possibly to confirm this interpretation. However the evolution of $\theta_{\mathrm{H} 2 \mathrm{O}}$ and $\theta_{\mathrm{I} 2 \mathrm{CH} 2}$ results in a regular decrease of $\gamma_{\mathrm{s}}$ from $45.3 \mathrm{~mJ} \mathrm{~m}^{-2}$ for UPEI $\left(\gamma_{\mathrm{s} \text { UPEI }}\right)$ to $27.4 \mathrm{~mJ} \mathrm{~m}^{-2}$ for FPEI $\left(\gamma_{\mathrm{s}}\right.$ FPEI $)$. This hydrophobic behaviour can be mainly related to the strong decrease of $\gamma_{\mathrm{s}}{ }^{\mathrm{d}}$ slightly compensated by the increase of $\gamma_{\mathrm{s}}^{\mathrm{p}}$ (Tab. 3).

To try to find a better correlation between the experimental $\gamma_{\mathrm{s}}$ value and the composition of the copolymers, we ploted the predicted curve obtained from the equation similar to the previous Fox equation. In the following equation (equation 4):

$$
1 / \gamma_{\mathrm{s}}=\mathrm{z} / \gamma_{\mathrm{s} \text { FPEI }}+(1-\mathrm{z}) / \gamma_{\mathrm{s} \text { UPEI }}
$$

$\gamma_{\mathrm{s}}$ replaces $\mathrm{T}_{\mathrm{g}}$ and $\mathrm{z}$ represents an undefined percentage value from $0 \%$ to $100 \%$. The curve a) in Fig. 9 shows $\gamma_{s}$ versus z. Then we ploted the $\gamma_{s}$ values versus experimental y and w TFD unit fractions in order to conclude the best correlation.

A non linear curve fitting method gave a correlation coefficient better for $z=y(r=0.99515)$ than for $z=w(r=0.98887)$. Although the $r$ values are close, it seems that the y experimental values are in better agreement with the predicted curve. So, the surface energy will be better analyzed in this polymer series by considering the TFD unit molar fractions incorporated in the copolymer. 
Based on the additivity principle we can suggest that a fall of $1 \mathrm{~mJ} \mathrm{~m}^{-2}$ is approximately due to a supplementary incorporation of 0.05 TFD unit molar fraction, this result coming from the calculation of the average slope of the curve. The additivity principle means that a large number of properties, including surface energy [18], when expressed per mole of a substance, may be calculated by summation of either atomic, group or bond contributions.

\section{Conclusions}

Fluorinated copolyetherimides based on the $\mathrm{ULTEM}^{\mathrm{TM}}$ structure have being synthesized by incorporating increasingly TFD units in the main chain from an original diamine bearing a long side chain $\mathrm{R}_{\mathrm{F}}=-\mathrm{CH}_{2}-\mathrm{C}_{6} \mathrm{~F}_{13}$. The combination of the ether linkage with the aliphatic chain segment and the $\mathrm{R}_{\mathrm{F}}$ side chain led to an increase in polymer flexibility that was estimated by taking into account the decrease in $\mathrm{T}_{\mathrm{g}}$ from $217^{\circ} \mathrm{C}$ to $113^{\circ} \mathrm{C}$ for UPEI and FPEI respectively. The thermal stability seems to be slightly weaker in the case of coFPEI however it remains enough for working these polymers in the membrane field. As the TFD units increase, $\gamma_{\mathrm{s}}$ decreases and consequently the hydrophobicity is steadily enhanced, furthermore these polymers are slowly soluble at ambient temperature in tetrahydrofuran and chloroform that is a good indication about their organophilic properties. The cast-evaporating method carried out in the case of coFPEI gave films with practical softness and mechanical strength enough to endure the pervaporation tests, typically $2-50 \mathrm{~h}$ transfer time, $25-50{ }^{\circ} \mathrm{C}$ temperature and 2-4 $\mathrm{mm} \mathrm{Hg}$ pressure. So, after staying in contact with water under these experimental conditions no damage, crack or hole were detected on the samples up to 0.75 molar fraction of TFD unit. On the opposite coFPEI with molar fraction higher than 0.75 and FPEI led to brittle and unusable films. The compromise between the chain mobility, thermal stability, hydrophobicity and material softness allows us to conclude that coFPEI with 0.75 TFD molar unit seems to be the optimized film $\left(\mathrm{T}_{\mathrm{g}}=121^{\circ} \mathrm{C}, \mathrm{T}_{\mathrm{d}} 5 \%=400{ }^{\circ} \mathrm{C}, \gamma_{\mathrm{s}}=30.8 \mathrm{~mJ} \mathrm{~m}{ }^{-2}\right)$. All things considered, the properties of these polymer series allows it to be evaluated as nonporous membranes for the extraction of traces of organic compounds from water.

\section{Experimental}

\subsection{Materials}


Diphthalic anhydride BAPA was kindly supplied by General Electric Plastics. m-phenylene diamine (m-PDA from Aldrich) and the solvent N-methylpyrrolidone (NMP from Aldrich) were used as received.

\subsection{Synthesis of the fluorinated diamine monomer}

The synthesis of the aliphatic diamine $2-(2,2,3,3,4,4,5,5,6,6,7,7,7$-tridecafluoroheptyl)butan1,4-diamine with $\mathrm{R}_{\mathrm{F}}=-\mathrm{CH}_{2}-\mathrm{C}_{6} \mathrm{~F}_{13}$ side chain called TFD in an abridged manner, has been already described in a detailed way elsewhere [12]. In brief, TFD was prepared from itaconic acid dimethyl ester (I) via the addition of perfluorohexyl iodide leading to the fluorinated diester (II) followed by the gradual transformation of ester groups in amino groups.

\subsection{Synthesis of copolyetherimides}

Fluorinated polyetherimide and copolyetherimides were prepared in NMP under argon atmosphere by heating at $120^{\circ} \mathrm{C}$ for $48 \mathrm{~h}$ a stoichiometric amount of BAPA and a diamine mixture made up of various molar fractions of m-PDA and TFD freshly synthesized. A partially imidized poly(ether amic acid) intermediate and the expected polyetherimide were first obtained. The mixture was precipitated in EtOH/H2O mixture. To improve the imidization state of the viscous copolymer mixture, the samples were dried in a vacuum oven at $140{ }^{\circ} \mathrm{C}$ for $12 \mathrm{~h}$. However the complete imidization was difficult to prove. The dehydration resulting from the reaction between the residual carboxylic acid and the amide groups led to the solid polyetherimides after solvent being eliminated (Tab.1).

\subsection{Films preparation and preliminary resistance-test}

The cast-evaporating technique was carried out using a $20 \%$ weight polymer solution in NMP for UPEI and in tetrahydrofuran or chloroform for coFPEI and FPEI. The slow-stirred solution at $80{ }^{\circ} \mathrm{C}$ for $4 \mathrm{~h}$ was cast on a glass plate and dried at $120^{\circ} \mathrm{C}$ under vacuum for $24 \mathrm{~h}$. Preliminary tests to evaluate the resistance of the films obtained from all compositions were achieved using a pervaporation cell with a total volume of $100 \mathrm{ml}$. The cell was filled with water, the pressure downstream from the film was $2-4 \mathrm{~mm} \mathrm{Hg}$ and the tests were carried out at $25-50{ }^{\circ} \mathrm{C}$ for $50 \mathrm{~h}$. Thus, we tried to find films showing practical softness and mechanical strength enough to endure the next pervaporation experiments. 


\subsection{Analysis and equipment}

${ }^{1} \mathrm{H}\left(400 \mathrm{MHz}, \mathrm{CDCl}_{3}\right)$ and ${ }^{19} \mathrm{~F}\left(235 \mathrm{MHz}\right.$ in $\left.\mathrm{CDCl}_{3}\right)$ NMR spectra were recorded with a Bruker AC instrument. Tetramethylsilane (TMS) and trichlorofluoromethane were used as internal reference for ${ }^{1} \mathrm{H}$ and ${ }^{19} \mathrm{~F}$ NMR spectra respectively. Molecular weights were determined by gel permeation chromatography (GPC) on a Waters instrument equipped with a differential refractometer, and the system was calibrated with polystyrene standards. Differential scanning calorimetry (DSC) data were taken on a Mettler DSC 30 instrument under an atmosphere of nitrogen, taking two scans at a heating rate of $10{ }^{\circ} \mathrm{C} \mathrm{min}^{-1}$. Tg were predicted using the Fox [13] and Couchman [14] methods (equations 5,6):

$$
1 / \mathrm{T}_{\mathrm{g}}=\mathrm{w}_{\mathrm{A}} / \mathrm{T}_{\mathrm{gA}}+\mathrm{w}_{\mathrm{B}} / \mathrm{T}_{\mathrm{gB}}
$$

$\ln \mathrm{T}_{\mathrm{g}}=\left(\mathrm{w}_{\mathrm{A}} \Delta \mathrm{Cp}_{\mathrm{A}} \ln \mathrm{T}_{\mathrm{gA}}+\mathrm{w}_{\mathrm{B}} \Delta \mathrm{Cp}_{\mathrm{B}} \ln \mathrm{T}_{\mathrm{gB}}\right) /\left(\mathrm{w}_{\mathrm{A}} \Delta \mathrm{Cp}_{\mathrm{A}}+\mathrm{w}_{\mathrm{B}} \Delta \mathrm{Cp}_{\mathrm{B}}\right)$

where $\mathrm{T}_{\mathrm{gA}}, \mathrm{T}_{\mathrm{gB}}$ and $\mathrm{w}_{\mathrm{A}}, \mathrm{w}_{\mathrm{B}}$ are the glass transition temperatures and the weigh fractions of the two components, respectively. $\Delta \mathrm{Cp}_{\mathrm{A}}$ and $\Delta \mathrm{Cp} \mathrm{p}_{\mathrm{B}}$ are the magnitudes of the incremental increase in heat capacity at $\mathrm{T}_{\mathrm{g}}$ of the pure components polymers.

Thermogravimetric analysis (TGA) was recorded with a Netzsch STA 409 thermobalance coupled with a mass spectrometer Baltzers QMG 421. This assembly allows to analyse the gas or volatile compounds released during the pyrolysis in the range $1-100 \mathrm{~m} / \mathrm{z}$. Thermogravimetric (TG) and derivative thermogravimetric (DTG) curves (DTG curves are not shown in the article) were recorded from $2 \mathrm{mg}$ samples at a heating rate of $10{ }^{\circ} \mathrm{C} / \mathrm{min}$ up to $900{ }^{\circ} \mathrm{C}$ under argon or air at a flow rate of $60 \mathrm{~mL} / \mathrm{min}$.

Static measurements of contact angles with water $\left(\theta_{\mathrm{H} 2 \mathrm{O}}\right)$ and diiodomethane $\left(\theta_{\mathrm{I} 2 \mathrm{CH} 2}\right)$, were made using a Kruss G1 apparatus. The $10 \% \mathrm{w}$ solution of polymers in THF was spread on a metal support, a smooth-thin film was obtained after the solvent evaporation. The accepted contact angles are the average of 6 measurements made on about $5 \mathrm{~s}$ after the liquid drop was 
deposited on the film surface. The surface energy $\left(\gamma_{\mathrm{s}}\right)$, the polar $\left(\gamma_{\mathrm{s}}^{\mathrm{p}}\right)$ and dispersive $\left(\gamma_{\mathrm{s}}{ }^{\mathrm{d}}\right)$ components were obtained from the Owens and Wendt method [17] (equation 7):

$$
(1+\cos \theta) \gamma_{L}=2\left(\gamma_{s}^{d}-\gamma_{L}^{d}\right)^{1 / 2}-2\left(\gamma_{s}^{p}-\gamma_{L}^{p}\right)^{1 / 2}
$$

where $\gamma_{\mathrm{L}}$ is the interfacial tension of the liquid $\left(\gamma_{\mathrm{LH} 2 \mathrm{O}}=72.8 \mathrm{~mJ} \mathrm{~m}^{-2}, \gamma_{\mathrm{L}}^{\mathrm{p}}{ }_{\mathrm{H} 2 \mathrm{O}}=51 \mathrm{~mJ} \mathrm{~m}^{-2}\right.$, $\gamma_{\mathrm{L}}{ }^{\mathrm{d}}{ }_{\mathrm{H} 2 \mathrm{O}}=21.8 \mathrm{~mJ} \mathrm{~m}^{-2}$ and $\gamma_{\mathrm{LCH} 2 \mathrm{I} 2}=50.8 \mathrm{~mJ} \mathrm{~m}^{-2}, \gamma_{\mathrm{L}}{ }^{\mathrm{p}}{ }_{\mathrm{CH} 2 \mathrm{I2}}=1.3 \mathrm{~mJ} \mathrm{~m}^{-2}, \gamma_{\mathrm{L}}{ }_{\mathrm{CH} 2 \mathrm{I} 2}^{\mathrm{d}}=49.5 \mathrm{~mJ} \mathrm{~m}^{-2}$ ).

\section{Acknowledgements}

We gratefully acknowledge the financial support obtained from the European Commission, TMR Research Networks, contract number ERBFM-RXCT 970120. We thank Dr Hubert Mutin and M Christian Curtil from the laboratory "Chimie Moléculaire et Organisation du Solide - Université Montpellier II" for hepful discussion and experimental assistance in GTA. 


\section{References}

[1] C.E. Sroog, in Polyimides-Fundamentals and Applications (Eds: M. K. Ghosh, K. L. Mittal), Marcel Decker, New York 1996, Ch. 1.

[2] H.R. Kricheldorf, Ed., Progress in polyimides chemistry, Springer, Berlin 1990

[3] W.D. Stenzenberger, P.M. Hergenrother, Eds, Polyimides, Blackie, London 1990

[4] R.H. Vora, P.S.G. Krishnan, S.H. Goh, T.S. Chung, Adv. Funct. Mater. 11 (2001) 361-372

[5] A. Jonquières, R. Clément, P. Lochon, J. Néel, M. Dresch, B. Chrétien, J. Membr. Sci. 206 (2002) 87-117

[6] B. Smitha, D. Suhanya, S. Sridhar, M. Ramakrishna, J. Membr. Sci. 241 (2004) 1-21

[7] J. Kurdi, A.Y. Tremblay, Polymer 44 (2003) 4533-4540

[8] Park, Byoung-Gi., Korean Journal of Chemical Engineering, 21 (2004) 882-889

[9] M. Kaba, N. Raklaoui, M.-F. Guimon, A. Mas, J. Appl. Polym. Sci. accepted for publication $\mathrm{n}^{\circ} 21684$ on november 17,2004

[10] M. Kayet, Applied Surface Sci. 238 (2004) 269-272

[11] M. Lahrhafi, A. Mas, P. Laurent, H. Blancou, F. Schué, Polym. Int. 48 (1999) 931-933

[12] R.E. Romero, A. Mas, Ph. Laurent, F. Schué, H. Blancou, J. Fluorine Chem., 117 (2002) 27-33

[13] T.G. Fox, Bull. Am. Phys. Soc. 1 (1956) 123-130 
[14] P.R. Couchman, Macromolecules 11 (1978) 1156-1161

[15] S. Carroccio, C. Puglisi, G. Montaudo, Macromol. Chem. Phys. 200 (1999) 2345-2355

[16] L.H. Perng, J. Appl. Polym. Sci. 79 (2001) 1151-1161

[17] D.K. Owens, R.C. Wendt, J. Appl. Sci. 13, (1969) 1741-1747

[18] Van Krevelen, Properties of polymers. Their estimation and correlation with chemical structure, Elsevier Scientific Publishing Company, Amsterdam 1976 


\section{List of Tables and Figures}

Table 1: Characteristics of polyetherimides

Table 2: Thermogravimetric characteristics of polyetherimides: degradation temperature for $5 \%\left(\mathrm{~T}_{\mathrm{d} 5 \%}\right)$ and $10 \%\left(\mathrm{~T}_{\mathrm{d} 10 \%}{ }^{*}\right)$ weight loss, temperature for maximum decomposition $\left(\mathrm{T}_{\max }\right)$

Table 3: Contact angle $\left( \pm 1^{\circ}\right)$ with water $\left(\theta_{\mathrm{H} 2 \mathrm{O}}\right)$ and diiodomethane $\left(\theta_{\mathrm{I} 2 \mathrm{CH} 2}\right)$, dispersive $\left(\gamma_{\mathrm{s}}{ }^{\mathrm{d}}\right)$ and polar $\left(\gamma_{\mathrm{s}}^{\mathrm{p}}\right)$ components of surface energy of polyetherimide films $\left(\gamma_{\mathrm{s}} \pm 1 \mathrm{~mJ} \mathrm{~m}^{-2}\right)$

Figure1: Scheme of the synthesis of polyetherimides (UPEI $y=0$, FPEI $x=0$, coFPEI $y \neq 0$ and $\mathrm{x} \neq 0)$

Figure 2: ${ }^{1} \mathrm{H}$ NMR spectra of UPEI $\mathrm{y}=0 \mathrm{x}=1$ (a), coFPEI 25/75 $\mathrm{y}=0.25, \mathrm{x}=0.75$ (b), FPEI $\mathrm{y}=1, \mathrm{x}=0(\mathrm{c})$

Figure 3: ${ }^{19} \mathrm{~F}$ NMR spectrum of coFPEI $75 / 25 \mathrm{y}=0.75, \mathrm{x}=0.25$

Figure 4: Glass transition temperature versus TFD unit weight fraction (w) for polyetherimides: experimental relationship (a), predicted relationship from Fox equation (b), predicted relationship from Couchman equation (c)

Figure 5: Thermogravimetric analysis of polyetherimides under argon (a) and under air (b)

Figure 6: MS spectrum of UPEI at $533^{\circ} \mathrm{C}$ under argon $\left(\mathrm{a}_{1}\right)$ and evolution profiles of the ions versus the temperature $\left(a_{2}\right)$ to $\left(a_{5}\right)$. The number next to each curve is the mass of the ion

Figure 7: MS spectrum of FPEI at $508^{\circ} \mathrm{C}$ under argon $\left(b_{1}\right)$ and evolution profiles of the ions versus the temperature $\left(b_{2}\right)$ to $\left(b_{5}\right)$. The number next to each curve is the mass of the ion 
Figure 8: Scheme of the thermal degradation of FPEI under argon: main pyrolysis products (as UPEI) (a), possible way yielding to benzonitrile (b), main pyrolysis products from TFD unit (c)

Figure 9: Surface energy $\left(\gamma_{\mathrm{s})}\right.$ of polyetherimide films versus TFD unit fraction: values calculated from the equation $1 / \gamma_{\mathrm{s}}=\mathrm{z} / \gamma_{\mathrm{s} \text { FPEI }}+(1-\mathrm{z}) / \gamma_{\mathrm{s} \text { UPEI }}(\circ)$ (curve a), experimental values versus TFD unit molar fraction $\mathrm{y}(\bullet)$ and weight fraction $\mathrm{w}(\mathrm{x})$. To simplify the figure the curves $\gamma_{\mathrm{s}}$ versus y and $\mathrm{w}$ are not drawn 
Table 1

TFD monomer unit $\quad$ Fluorine wt \%

\begin{tabular}{cccccccc}
\cline { 2 - 6 } Polyetherimide & $\mathrm{y}^{\mathrm{a}}$ & $\mathrm{w}^{\mathrm{b}}$ & $\mathrm{NMR}^{\mathrm{c}}$ & $\begin{array}{c}\text { Elementary } \\
\text { anaylsis }\end{array}$ & $\mathrm{M}_{\mathrm{w}}{ }^{\mathrm{e}}$ & $\mathrm{M}_{\mathrm{n}}{ }^{\mathrm{e}}$ & $\mathrm{T}_{\mathrm{g}}^{\mathrm{f}}\left(\Delta \mathrm{C}_{\mathrm{p}}\right)^{\mathrm{f}}$ \\
\hline UPEI & 0 & 0 & 0 & 0 & 30000 & 12000 & $217(0.12)$ \\
coFPEI 25/75 & 0.25 & 0.34 & 9.2 & 6.9 & 28000 & 11000 & $172(0.17)$ \\
coFPEI 50/50 & 0.50 & 0.60 & 16.6 & 13.9 & 24000 & 7000 & $145(0.20)$ \\
coFPEI 75/25 & 0.75 & 0.82 & 22.4 & 17.7 & 43500 & 15600 & $121(0.13)$ \\
FPEI & 1 & 1 & 27.3 & 23.7 & 12200 & 6000 & $113(0.15)$ \\
\hline
\end{tabular}

${ }^{a}$ Molar fraction of fluorinated monomer units incorporated in polyetherimides

${ }^{\mathrm{b}}$ Weight fraction of fluorinated monomer units incorporated in polyetherimides

${ }^{\mathrm{c}}$ Fluorine weight percentage deduced from NMR

${ }^{\mathrm{d}}$ Fluorine weight percentage deduced from elementary analysis

${ }^{\mathrm{e}}$ Molecular weight determined in THF for fluorinated polyetherimides and molecular weight values of marketed ULTEM ${ }^{\mathrm{TM}}\left(\mathrm{g} \mathrm{mol}^{-1}\right)$ for UPEI

${ }^{\mathrm{f}}$ Glass transition temperature $\mathrm{T}_{\mathrm{g}}\left({ }^{\circ} \mathrm{C}\right)$ and heat capacity $\Delta \mathrm{C}_{\mathrm{p}}\left(\mathrm{J} \mathrm{g}^{-1} \mathrm{~K}^{-1}\right)$ 
Table 2

\begin{tabular}{|c|c|c|c|c|c|c|}
\hline \multirow{2}{*}{ Polyetherimides } & \multicolumn{3}{|c|}{ Under argon } & \multicolumn{3}{|c|}{ Under air } \\
\hline & $\mathrm{T}_{\mathrm{d} 5 \%}$ & $\mathrm{~T}_{\max }$ & $\begin{array}{c}\% \text { residue } \\
\text { over } 800^{\circ} \mathrm{C}\end{array}$ & $\mathrm{T}_{\mathrm{d} 5 \%}$ & $\mathrm{~T}_{\max }$ & $\begin{array}{l}\% \text { residue } \\
\text { over } 800^{\circ} \mathrm{C}\end{array}$ \\
\hline \multirow[t]{2}{*}{ ULTEM $^{\mathrm{TM}}$} & 520 & $545^{*}$ & 48 & 520 & 540 & 0 \\
\hline & & 585 & & & 700 & \\
\hline \multirow[t]{2}{*}{ UPEI } & 500 & $533^{*}$ & 52 & 500 & 531 & 0 \\
\hline & & 585 & & & 686 & \\
\hline \multirow[t]{2}{*}{ coFPEI 25/75 } & $400 *$ & 540 & 41 & $370 *$ & 520 & 0 \\
\hline & & - & & & 640 & \\
\hline \multirow[t]{2}{*}{ coFPEI 50/50 } & 400 & 510 & 39 & 370 & 480 & 0 \\
\hline & & - & & & 640 & \\
\hline \multirow[t]{2}{*}{ coFPEI 75/25 } & 400 & 510 & 31 & 370 & 460 & 0 \\
\hline & & - & & & 640 & \\
\hline \multirow[t]{2}{*}{ FPEI } & 460 & 440 & 13 & 440 & 501 & 0 \\
\hline & & $508^{*}$ & & & 627 & \\
\hline
\end{tabular}


Table 3

\begin{tabular}{cccccc}
\hline Polyetherimides & $\begin{array}{c}\theta_{\mathrm{H}_{2} \mathrm{O}} \\
\left({ }^{\circ}\right)\end{array}$ & $\begin{array}{c}\theta_{\mathrm{CH}_{2} \mathrm{I}_{2}} \\
\left(^{\circ}\right)\end{array}$ & $\begin{array}{c}\gamma_{S}^{d} \\
\mathrm{~mJ} \mathrm{~m}^{-2}\end{array}$ & $\begin{array}{c}\gamma_{S}^{P} \\
\mathrm{~mJ} \mathrm{~m}^{-2}\end{array}$ & $\begin{array}{c}\gamma_{S} \\
\mathrm{~mJ} \mathrm{~m}^{-2}\end{array}$ \\
\hline ULTEM $^{\mathrm{TM}}$ & 93.0 & 27.0 & 46.7 & 0.1 & 46.8 \\
UPEI & 88.0 & 32.0 & 44.5 & 0.8 & 45.3 \\
coFPEI 10/90 & 84.4 & 33.3 & 41.0 & 2.0 & 43.0 \\
coFPEI 18/82 & 84.6 & 36.6 & 37.5 & 2.5 & 40.0 \\
coFPEI 25/75 & 82.0 & 45.2 & 34.1 & 4.0 & 38.1 \\
coFPEI 50/50 & 82.0 & 51.0 & 30.5 & 5.0 & 35.5 \\
coFPEI 75/25 & 85.4 & 59.4 & 26.1 & 4.7 & 30.8 \\
coFPEI 90/10 & 90.4 & 61.0 & 26.0 & 3.0 & 29.0 \\
FPEI & 92.0 & 68.0 & 24.6 & 2.8 & 27.4 \\
\hline
\end{tabular}


<smiles>Nc1cccc(N)c1</smiles>

m-PDA or/and<smiles>NCCC(CN)CC(F)(F)F</smiles>

TFD<smiles>CC(C)(c1ccc(Oc2ccc3c(c2)C(=O)OC3=O)cc1)c1ccc(Oc2ccc3c(c2)C(=O)OC3=O)cc1</smiles>

$$
\begin{aligned}
& \text { N-methyl pyrrolidone } \\
& \Delta 120^{\circ} \mathrm{C} \\
& 48 \mathrm{~h}
\end{aligned}
$$

Fluorinated poly(ether amic acid) intermediate

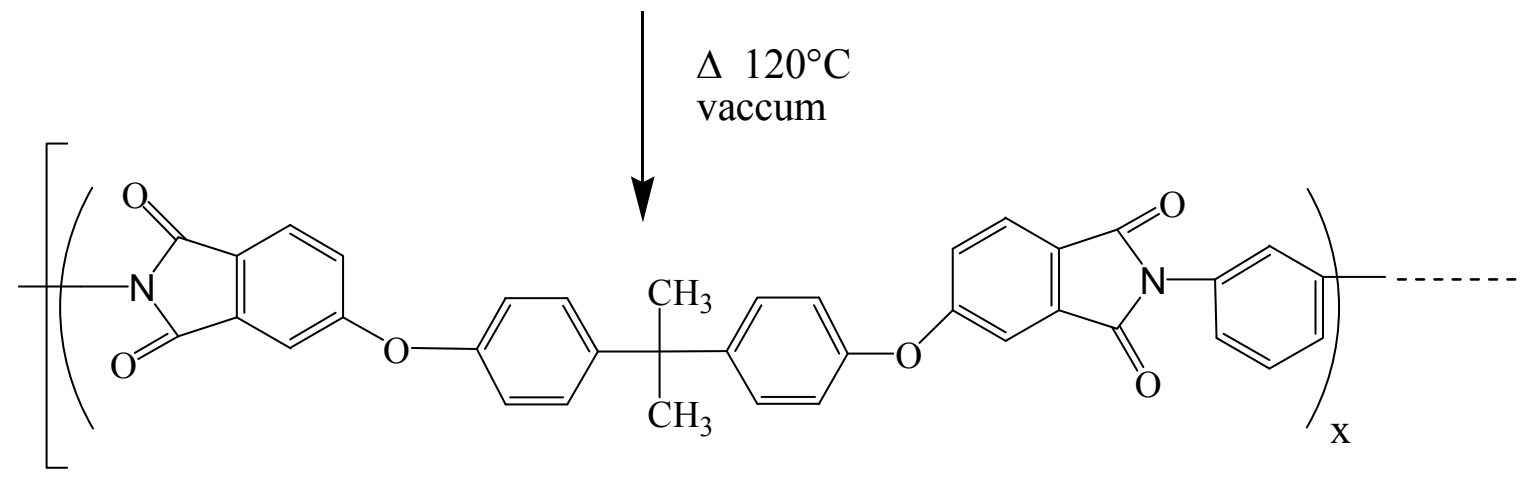<smiles></smiles>

Fluorinated polyetherimide

Figure 1 
(a)
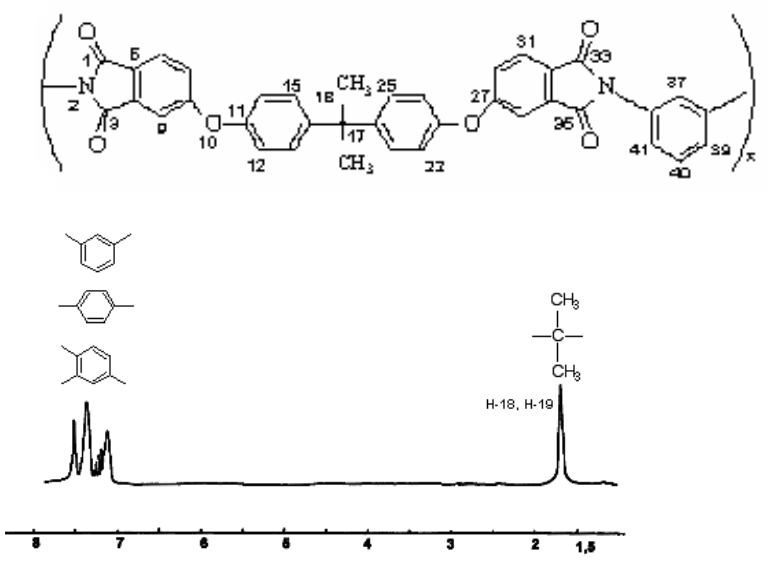

(b)

(c)
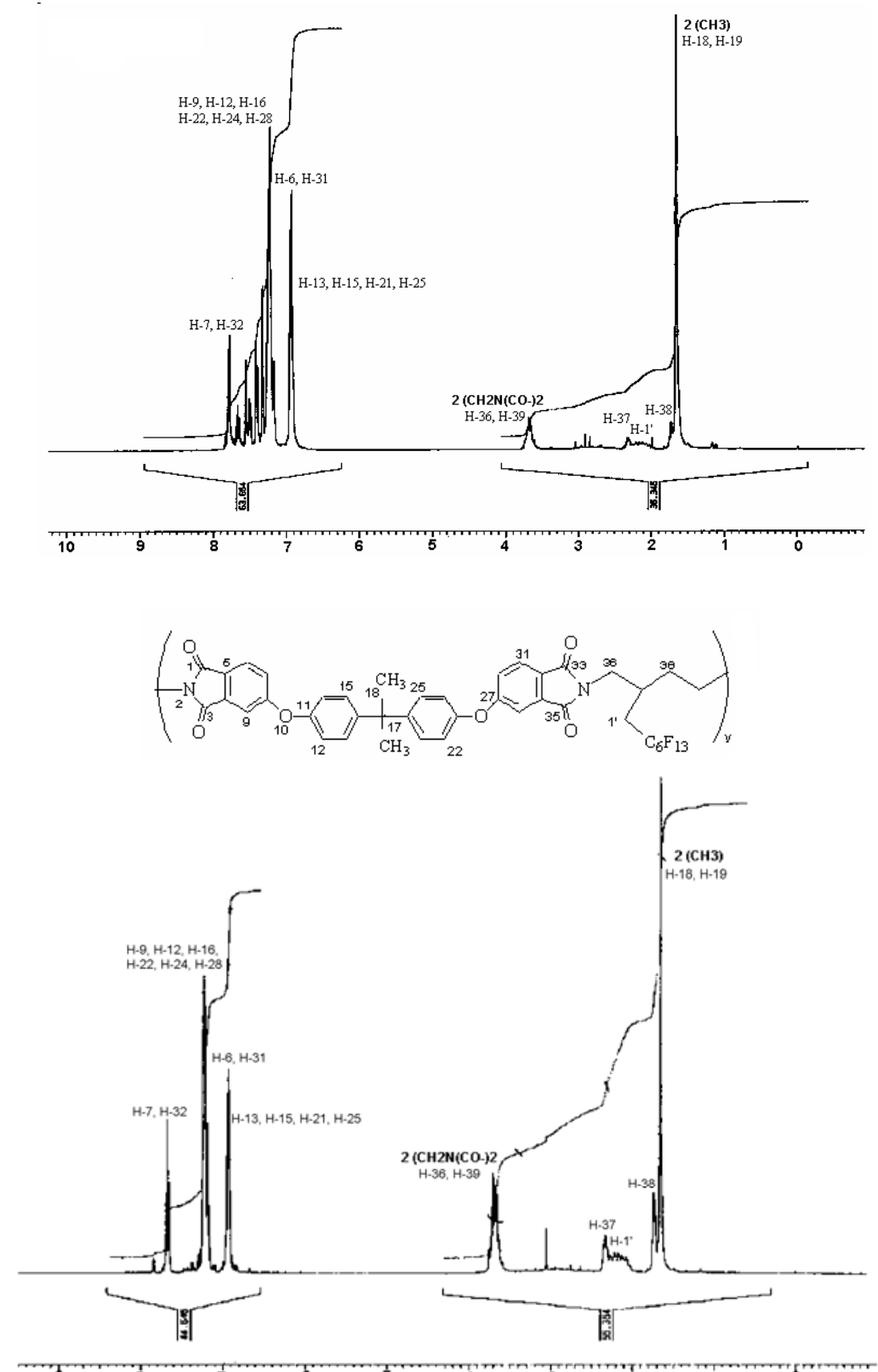

Figure 2 


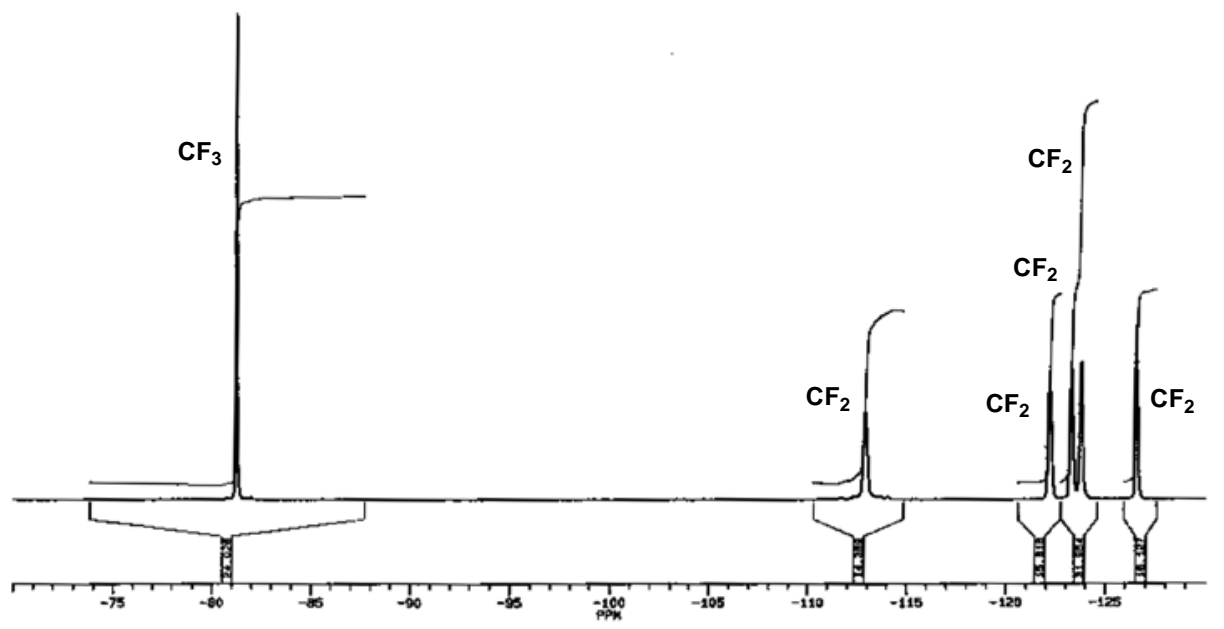

Figure 3 


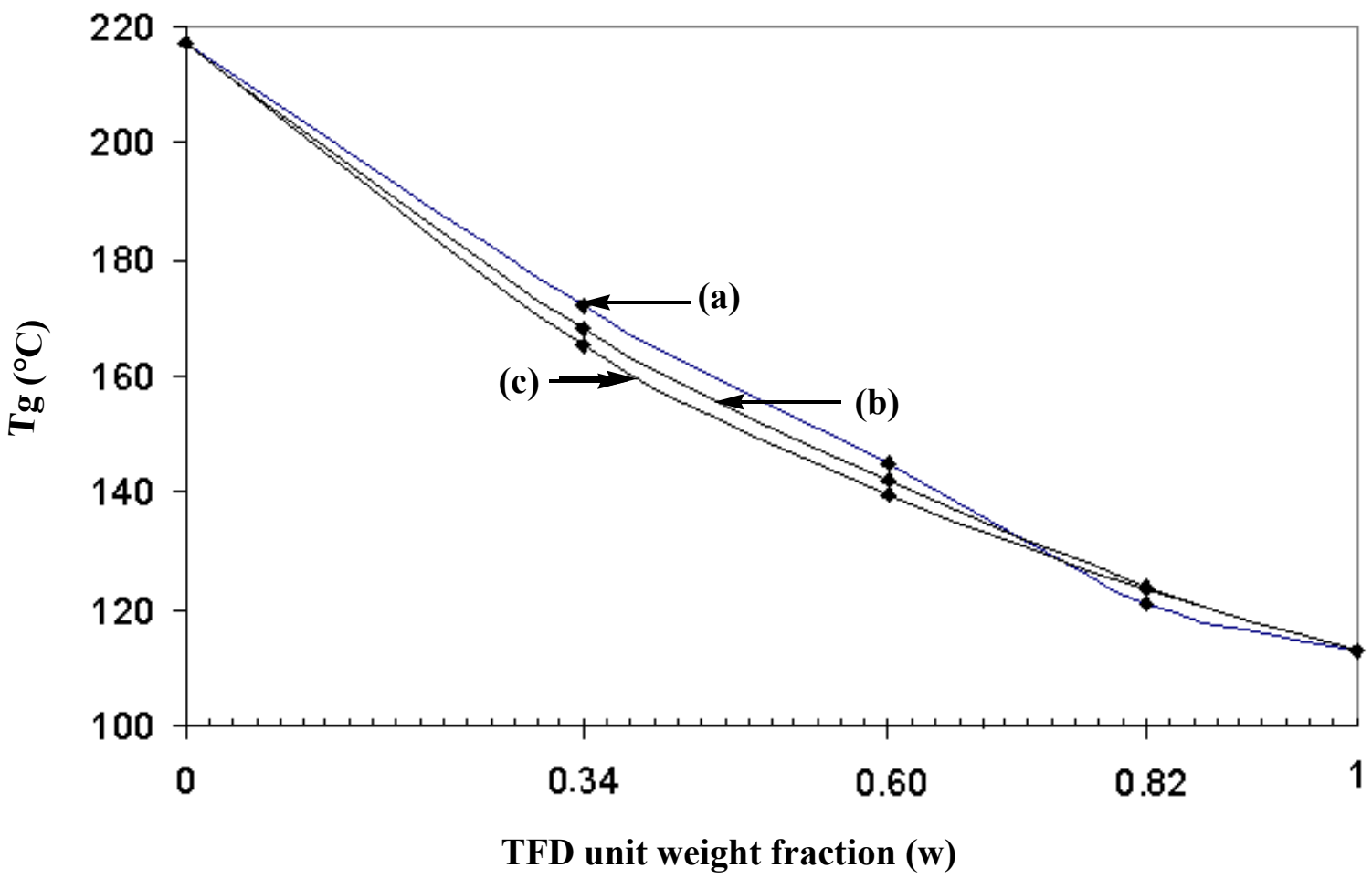

Figure 4 


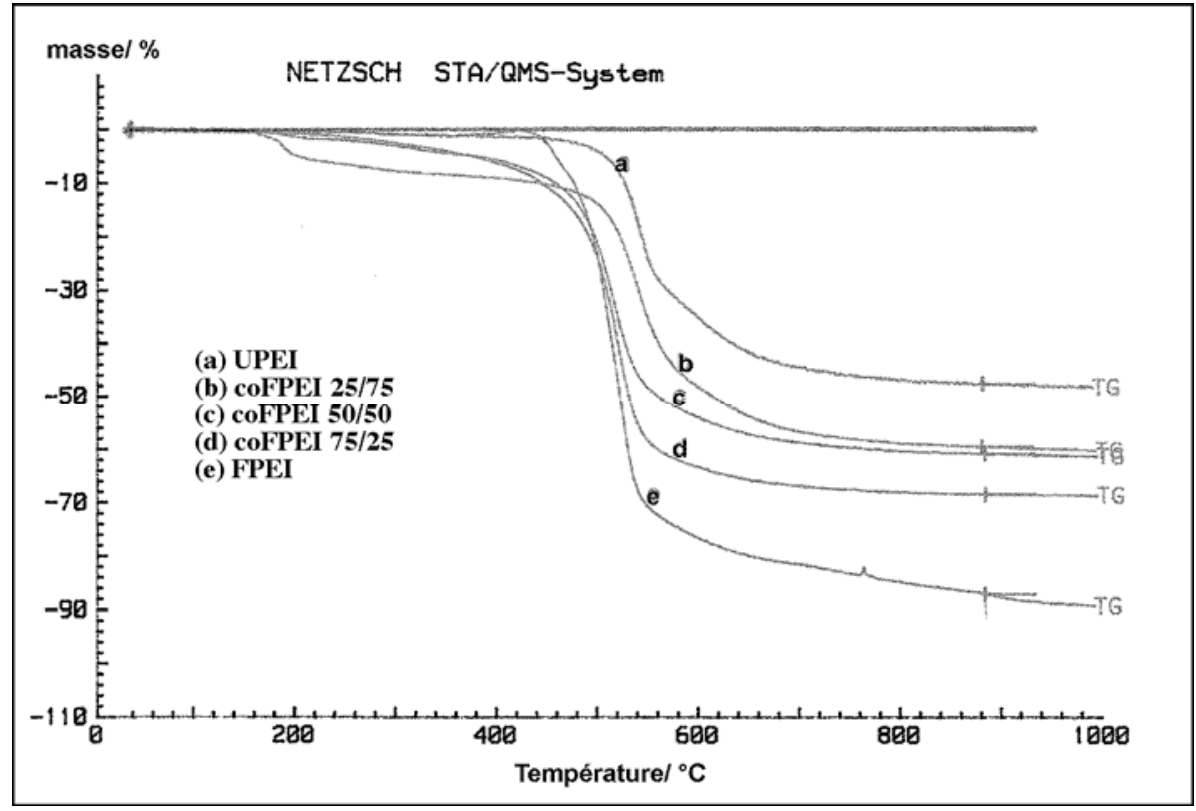

(b)

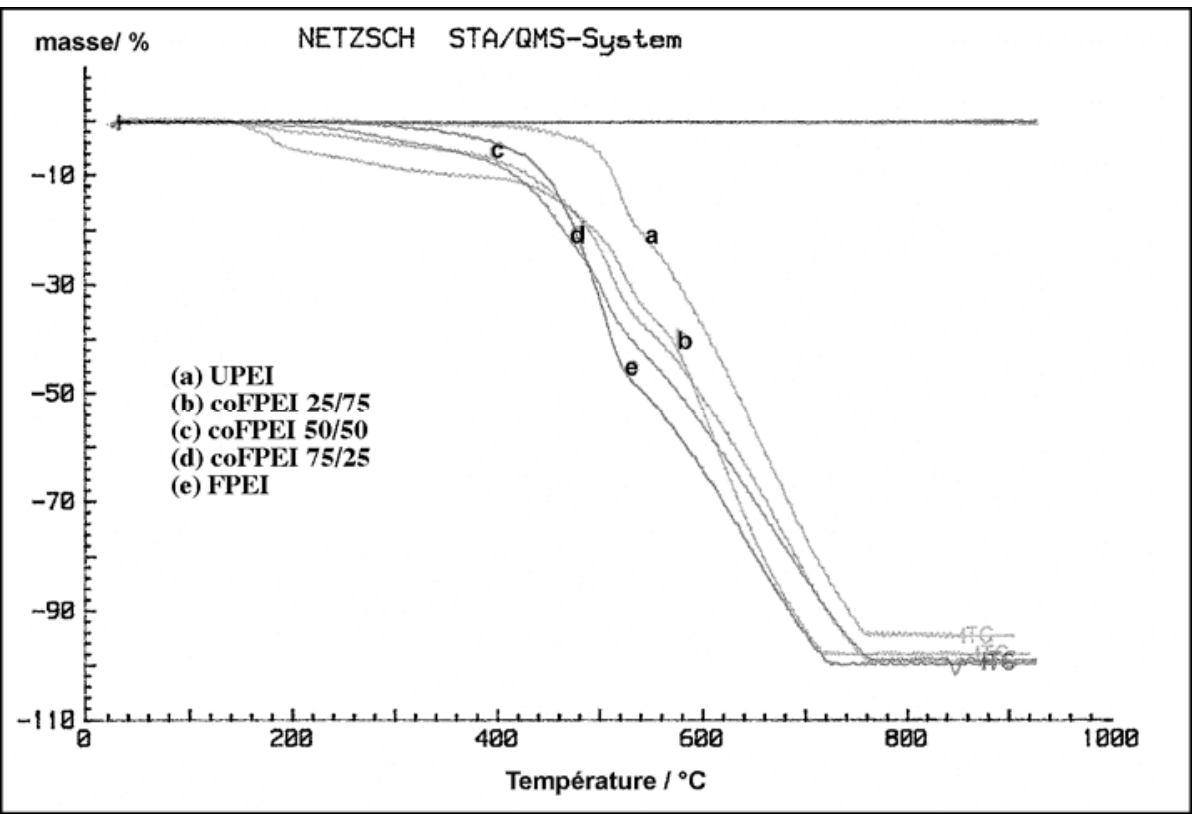

Figure 5 

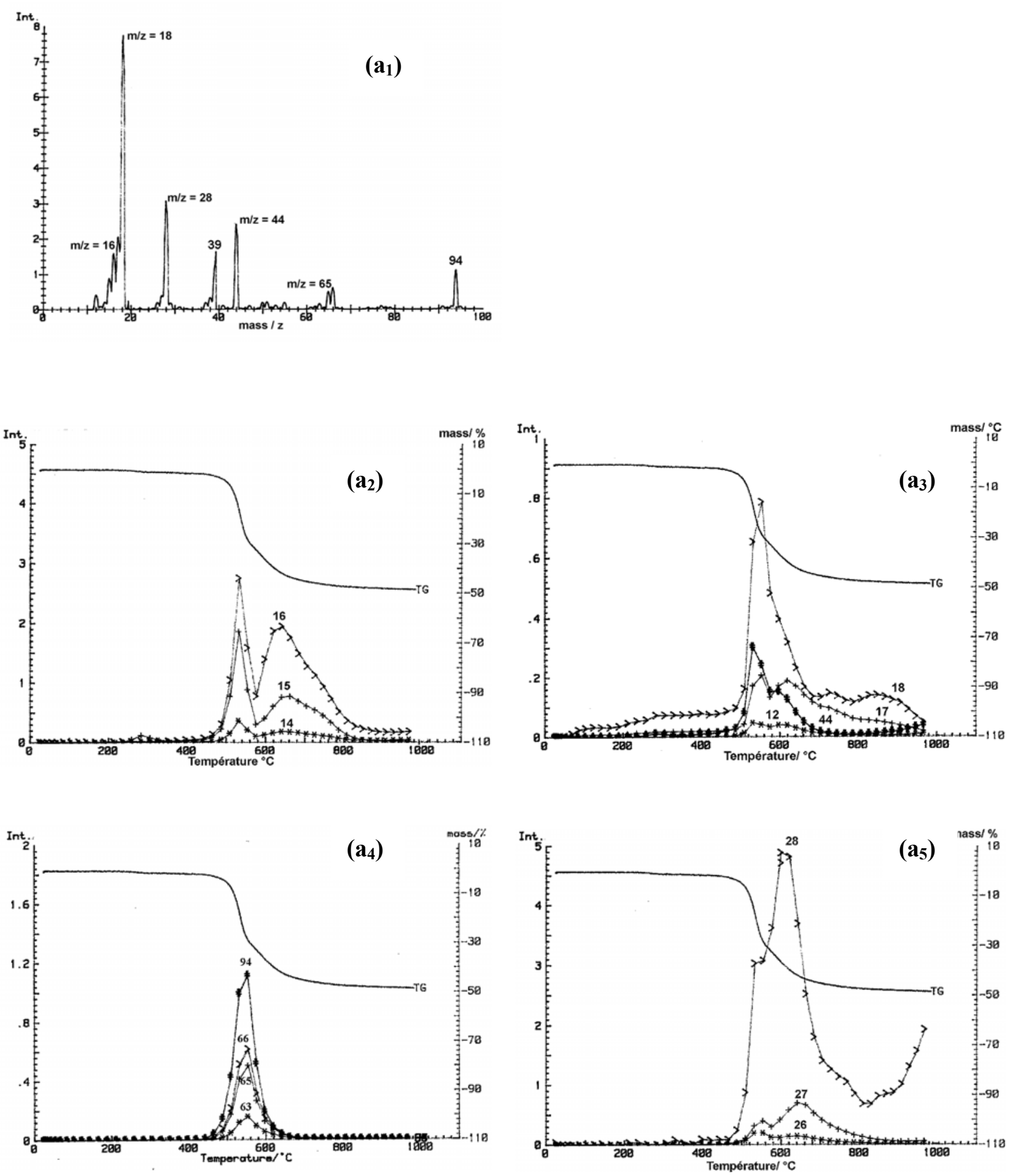

Figure 6 

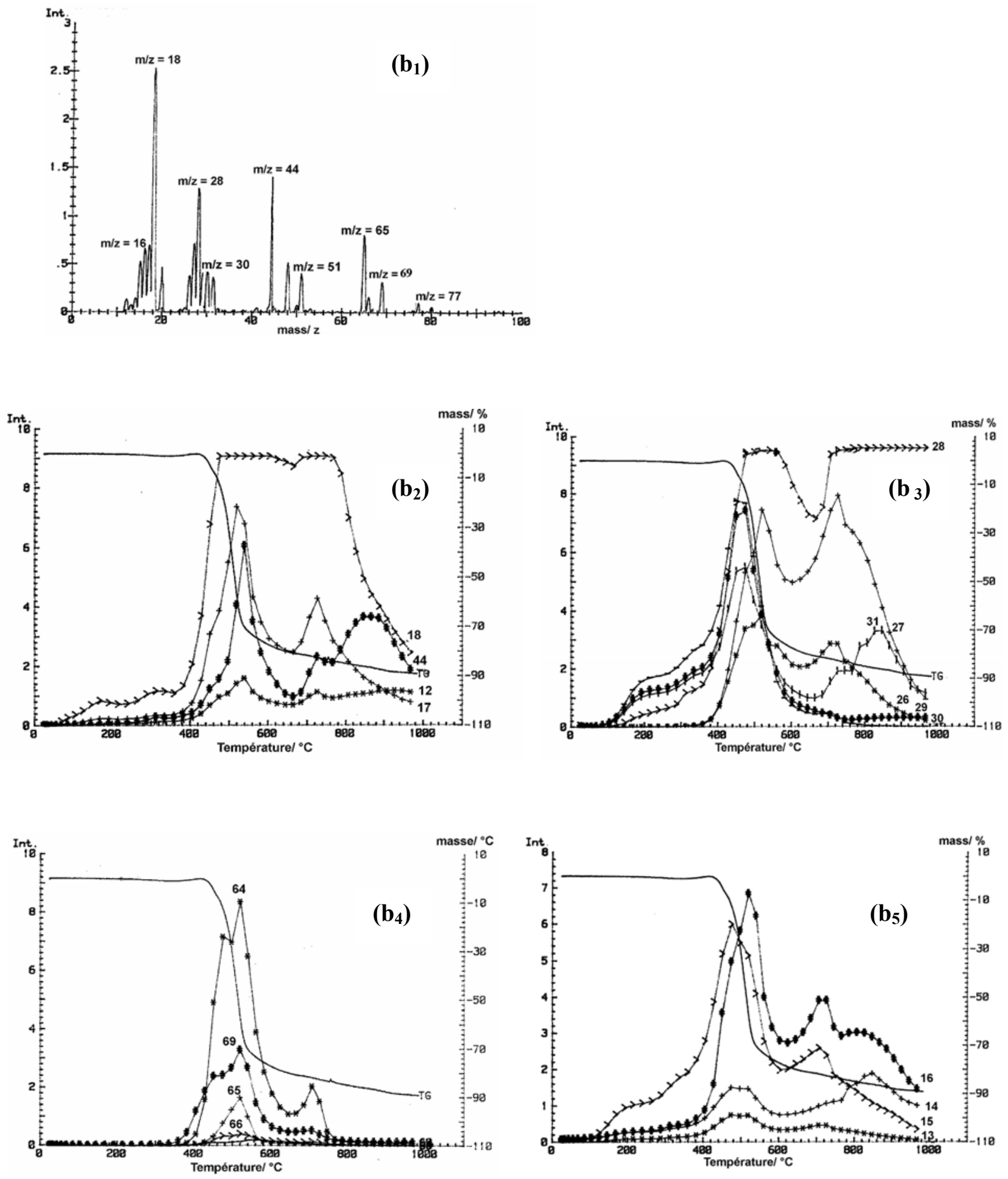

Figure 7 

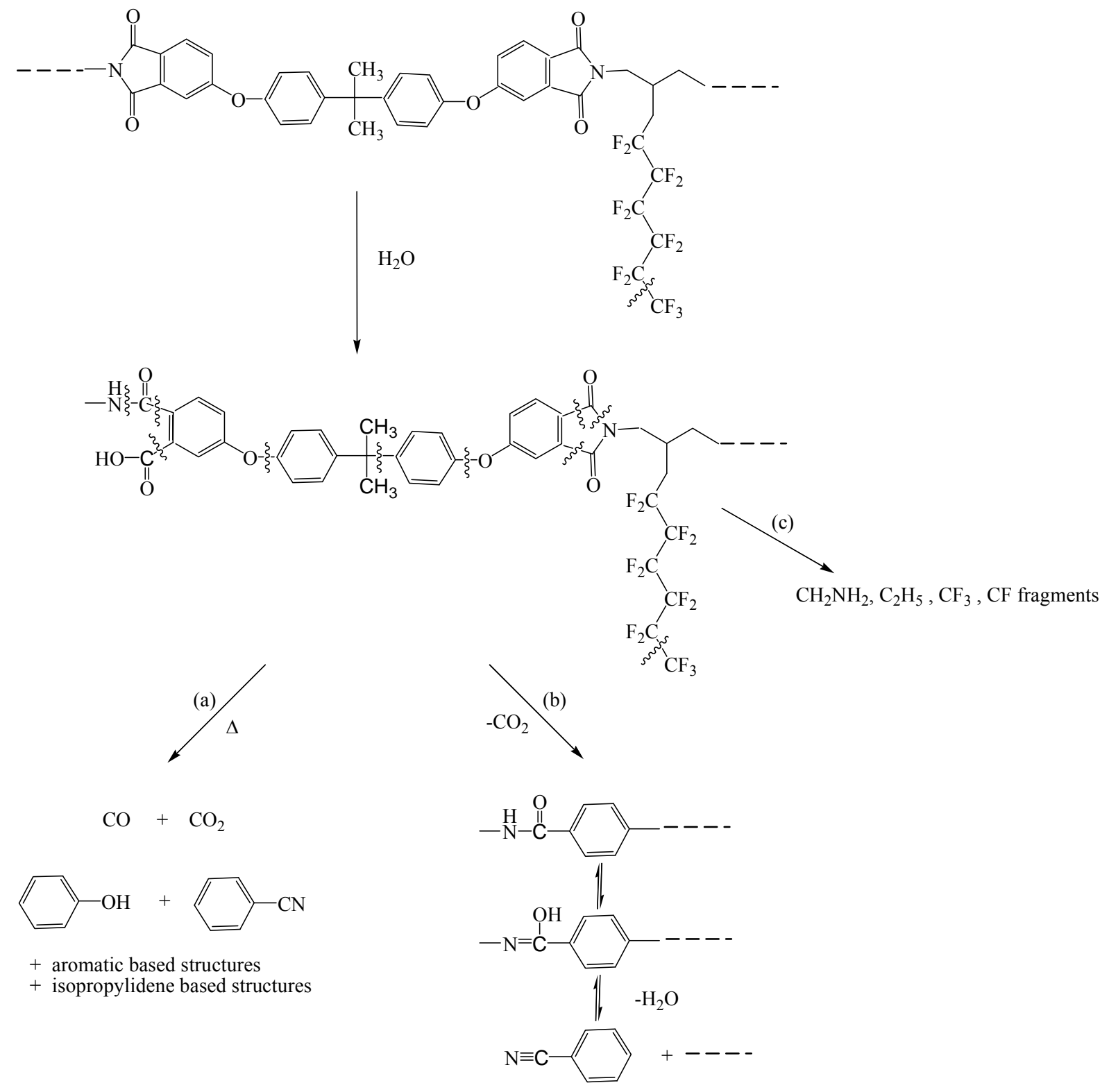

+ aromatic based structures

+ isopropylidene based structures

Figure 8 


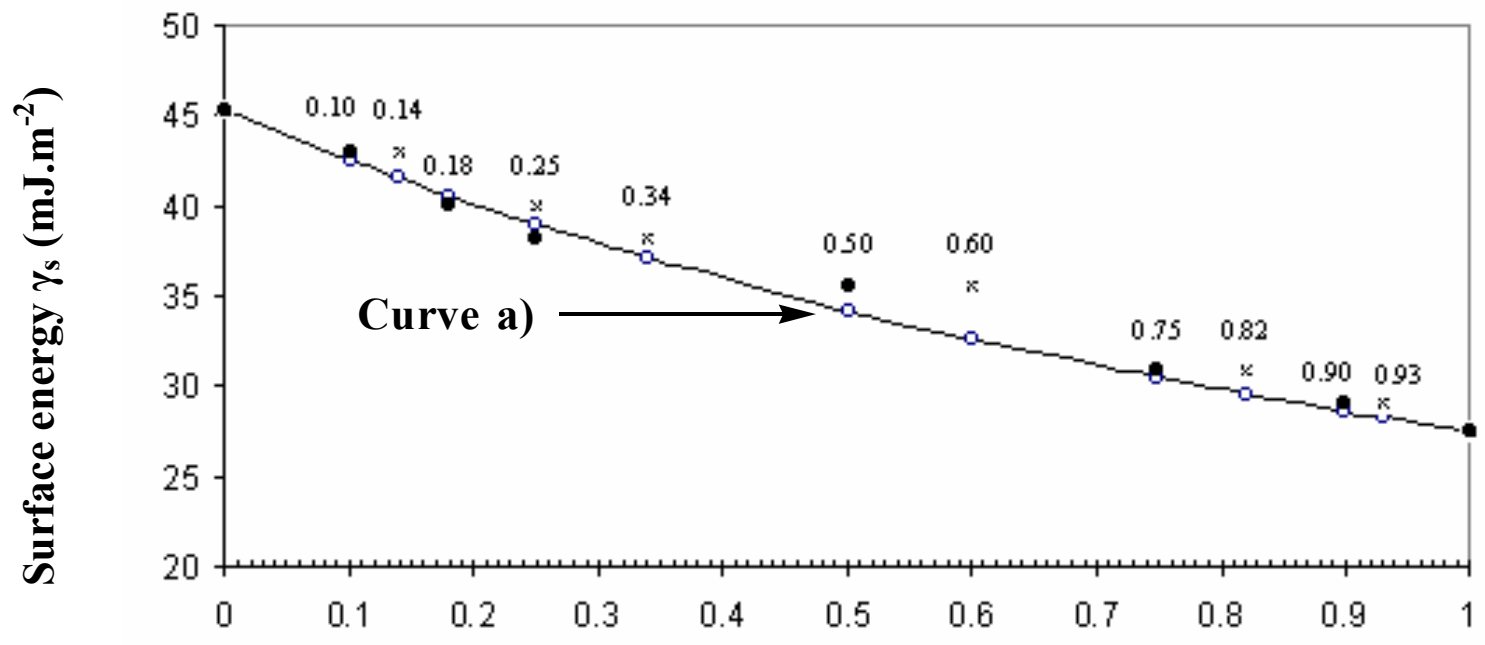

TFD unit fraction

Figure 9 